\title{
DESIGNING AN ESP WRITING COURSE FOR PRE-INTERMEDIATE EFL ENGINEERING STUDENTS
}

\author{
Burak Tomak $^{1}$, Ufuk Ataş ${ }^{2}$ \\ ${ }^{1}$ Marmara University, ${ }^{2}$ Artvin Çoruh University, Turkey \\ E-Mails: ${ }^{1}$ buraktomak@hotmail.com, ${ }^{2}$ atasufuk@gmail.com
}

\begin{abstract}
This paper reports the whole process on an attempt to design an ESP English Writing Course $(E W C)$ at a pre-intermediate level for engineering students studying at English medium departments at a state university in Turkey. Designing an English Writing Course specific for engineering students is necessary since the current EWC fails to provide the students with necessary preparations for their future careers as well. Based on Hyland's (2003) guiding concepts for teaching L2 writing and following the Language Curriculum Design Model of Nation \& Macalister (2010), we aim to design an EWC that will equip engineering students with specific content and terminology as well as giving them a chance to practice writing in a way that will be sufficient for their future studies at their departments and future academic and professional careers. Data were collected via face-to-face interviews with preparatory school students and instructors as well as faculty of engineering students and an instructor. Using qualitative content analysis, the needs, wants, and lacks were determined and an ESP English Writing Course Syllabus is offered as a result of this study which provides implications for developing writing skills of the mentioned group, as well as other ESP writing course contexts.
\end{abstract}

Key words: EAP, English writing course, course development, needs analysis

\section{INTRODUCTION}

In today's world, the ability to write effectively carries great importance; thus, instruction on how to write effectively has a significantly increasing role in both second and foreign language education as a means to serve for educational, business and personal reasons (Weigle, 2002, Nation, 2009). In addition to this, writing skill is directly linked to communication. As Olshtain (2001) elaborates, "it is via writing that a person can communicate a variety of messages to a close or distant, known or unknown reader or readers" (p. 207). Whether this communication takes the form of the common pencil-andpaper writing or in ways of technological versions such as e-mails, communication by means of writing is surely important in the modern world (Olshtain, 2001).

This paper reports the whole process on an attempt to design an English Writing Course at a pre-intermediate level for engineering faculty students studying at English medium departments at a state university in Turkey. Designing an English Writing Course (EWC) specific for engineering students is necessary for three reasons. Firstly, current EWCs offered at the School of Foreign Languages at the university fail to equip 
engineering students with necessary skills and qualifications required at their major departments. Although the overall aim of the English Preparatory School is to enable the students to acquire the proficiency and language skills required for their undergraduate studies in the English-medium departments, these language skills the School provides for engineering students fall short of the specific language skills they need when they go to their major departments. Secondly, due to the heterogeneous nature of the School in terms of learner profile, engineering students do not get the chance to practice appropriate writing skills which they certainly need in their departments because they get their education along with students enrolled in other departments in other faculties. Thus, content and terminology specific to the field of engineering cannot be addressed adequately in EWCs, which makes it hard for these students to continue any writing practices when they go to their own departments. Thirdly, students graduating from engineering departments continue their need to use their practical writing skills in their future academic and/or professional careers. The current EWC fails to provide the students with necessary preparations for their future careers as well.

Considering these three lacks in the current EWCs offered at the English Preparatory School, in this paper, we aim to design an EWC that aims to equip engineering students with both specific content and terminology, as well as giving them chance to practice writing in a way that will be sufficient for their future studies at their departments and future academic and/or professional careers.

Following the Language Curriculum Design Model of Nation \& Macalister (2010), a detailed analysis of environment and learner needs has been carried out. Deriving from the results of these analyses, overall principles that guide the EWC have been identified in their contributory effects to the organization of the course. Moving forward into the inner circle of Nation and Macalister's (2010) model, procedural steps of the course, including goals, content and sequencing, format and presentation, and monitoring and assessment were identified. Lastly, information about the evaluation phase of the course has also been given to determine the overall effectiveness of the course.

\section{WRITING AS A LANGUAGE SKILL}

In its broadest sense, writing is defined as the productive development and representation of thoughts in a structured way. In the literature, definitions of the ability in writing and what it includes are usually approached in comparison with either writing in the first language (Weigle, 2002) or how it differs from the ability of producing speech (Ur, 1996).

In contexts of foreign language courses, the need to gain sufficient writing ability is important since it constitutes a major part of students' academic achievement. For such achievement to occur, there are various approaches to teaching writing skills in English as a Foreign/Second Language (EFL/ESL) classrooms. Though such approaches differ in relation with the goals of a specific course or the student needs, what writers have to deal with as they produce a piece of writing bears more or less the same characteristics (Raimes, 1983). In the following diagram, these characteristics that involve producing a piece of writing are given in their relation with clear, fluent and effective communication of ideas (Raimes, 1983, p. 6). 


\section{SYNTAX}

Sentence structure, sentence boundaries, stylistic choices, etc.

\section{CONTENT}

Relevance, clarity, originality, logic, etc.

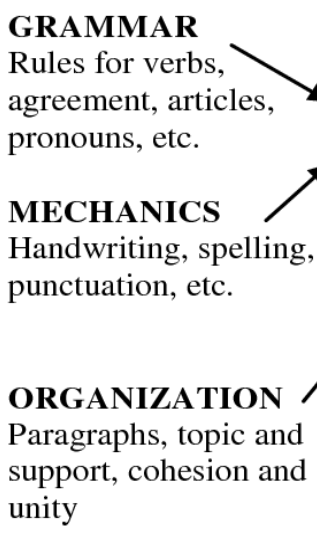

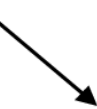
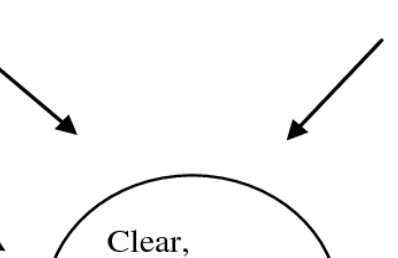
fluent, and effective communicat
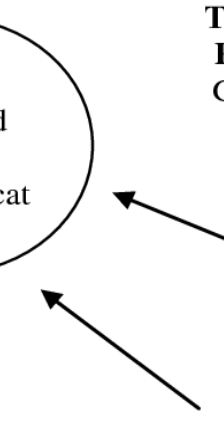

WORD CHOICE

Vocabulary, idiom, tone
THE WRITER'S PROCESS

Getting ideas, getting stared, writing drafts, revising

AUDIENCE

The reader/s

\section{PURPOSE}

The reason for writing

Fig 1 Producing a piece of writing (Raimes, 1983, p. 6)

Following this diagram, showing what writers deal with when writing, teachers and/or researchers develop different approaches to teach writing skills that focus on how they think writing is learned, by making a combination between the two (Raimes, 1983). For Ur (1996), there are three major ways in which writing can be used in a foreign language course: writing as a means, writing as an end, and writing as both means and end. From her approach, writing can simply be used as means of teaching other aspects of language, such as grammar or vocabulary. Also, some activities of writing might take it as the main objective, focusing primarily on practicing specific written forms at both micro (producing words or sentences) and macro (narrating a story or writing a letter) levels. A third approach to writing activities involve a combination of these two which focuses on purposeful and original writing with practicing other language skills and content, for instance, "a written response to the reading of a controversial newspaper article (combines writing with reading)" (Ur, 1996, p.11).

Hyland (2003) suggests some guiding concepts for teaching L2 writing, which include language structures, text functions, themes or topics, creative expression, composing process, content, genre and contexts of writing. He further asserts that different theories that support the guiding concepts in L2 writing have been translated into appropriate methodologies and applied into practice in classrooms depending on "what learners need to learn and what teachers need to provide for effective instruction" (p.2), without an emphasis on a strict reference to one of these orientations.

Based on these discussions on how to approach teaching writing, this study aims to develop an English Writing Course that can be used both as a means and an end, according to Ur's (1996) classification; as well as referring to certain language structures, themes and topics, content, genre and contexts of writing, according to Hyland's (2003) guiding concepts. 


\section{METHOD}

In this study, Nation and Macalister's (2010) model of language curriculum design which includes principles, needs, environment, content and sequencing, format and presentation, monitoring and assessment, goals and objectives, as well as evaluation was used. Environment analysis is an important part of the curriculum design process since "at its most basic level, it ensures that the course will be useful" (Nation \& Macalister, 2010 , p. 14). Ensuring that the course will be useful depends on various inner and outer factors that play a crucial role in designing a course. According to Nation \& Macalister (2010), needs analysis is directly related to what the course should aim and what content it should have derived from the examination of what the students already know and need to know. As Richards (2001) states, a sound educational system needs to be based on learners' needs analysis. Therefore, it is also a crucial preliminary phase of language curriculum design since the steps to follow will be based on the results of such analysis. Our fundamental consideration in the needs analysis circulates around three major constraints: necessities, lacks and wants of the learners. Along with these, other components of the model have also been considered: principles, content and sequencing, format and presentation, goals and objectives, and evaluation. Figure 2 shows the language curriculum design model.

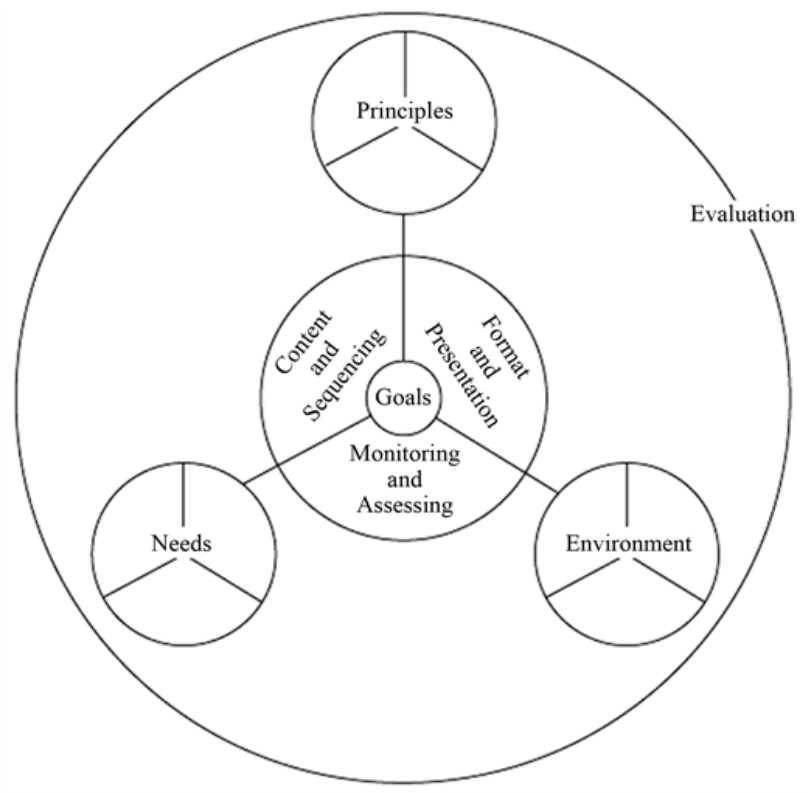

Fig 2 Language curriculum design model by Nation \& Macalister (2010)

\subsection{Participants}

The participants for the study include: seven students studying at the preparatory school, eight third year students (juniors) at the Faculty of Engineering, three language instructors teaching language skills at the preparatory school for which this course was designed and one instructor at the Faculty of Engineering. By selecting these participants 
for conducting interviews for needs analysis, the purpose was to include opinions of a diverse group to come up with an effective course design. For instance, the $3^{\text {rd }}$ year engineering students had taken a Writing Course when they were studying at the preparatory school. Now they are taking course at their major departments and they have already completed their business practicum. This makes them eligible to evaluate the influence of the writing course they have taken both on their current academic life and their career as prospective engineers. Therefore, their thoughts, ideas and comments are considered to be important because their experiences were consulted to build on the development of future writing courses. On the other hand, preparatory school students are the ones this writing course is designed for. Therefore, their wants, lacks and necessities were considered in designing the course. Since preparatory school instructors who have been selected to be interviewed have the experience of teaching a writing course specifically for engineering students, their ideas on any aspect of a prospective writing course were also considered. Last but not least, the ideas of the faculty members on the writing competence of the engineering students are equally important. Therefore, an assistant professor from the Faculty of Engineering was also interviewed.

The learners of this university from which participants were chosen have high scores from the University Entrance Exam applied nationwide. Turkish is the native language for nearly all of these students, so they share the same cultural and linguistic backgrounds. Yet, they are coming from diverse parts of Turkey which brings socio-cultural variety into the classroom. Since the learners will be the students at various departments at the Faculty of Engineering which uses English as a medium of instruction, they have to acquire English writing skills both for their departmental courses and their future careers.

\subsection{Data Collection}

The main data collection tool used in this study is interviews with the participants. Alongside the interviews, since one of the researchers in this project was teaching at the particular institution for which the particular EWC is designed for, made him a participant researcher; his observations were consulted in determining the environmental constraints. Additionally, wider aspects of the situation have also been considered, such as the status of the target language in the national context and the opportunity to use the target language outside the classroom. In order to gather data for needs analysis, several interviews were conducted with different groups of learners and teachers. The interviews consisted of eight questions each and there were three sets of questions designed specifically for teachers, students who have taken a writing course at the preparatory school and students who are going to take a writing course at the preparatory school. These face-to-face interviews lasted around 15 to 30 minutes each. The language of the interview was Turkish to make participants express themselves well. Participants were asked to fill consent forms for voluntary participation and were informed that they could give up at any time without any penalties. 


\section{RESULTS}

According to the data collected via interviews, the needs, wants and wishes of these participants were determined separately for the four groups of participants: preparatory school students, $3^{\text {rd }}$ year engineering faculty students, preparatory school instructors, and an engineering faculty member.

\subsection{Needs Analysis}

As Table 1 shows, the students want a writing course to help improve their vocabulary and grammar so that they are be able to relate these in their departmental studies. Specific wants include the ability to read, understand and analyse articles related to engineering, gaining skills to help them write their departmental assignments and projects. Additionally, there were students who stated that they would like to continue their education towards an M.A. or Ph.D. degree, and that a writing course should also allow them to gain necessary skills in writing theses.

Table 1 Needs analysis results of preparatory school students

\begin{tabular}{|l|l|}
\hline Wants & $\begin{array}{l}\text { - improving vocabulary and grammar knowledge } \\
\text { - being able to use the things they learn at the } \\
\text { departments }\end{array}$ \\
- making use of this knowledge in their careers \\
(job application, business transactions, writing e- \\
mails and reports, etc.)
\end{tabular}


Third year engineering students were also asked to make some comments on the content of the writing course that they had taken when they were in the preparatory school, as well as some of the possible modifications that should be done. Table 2 shows their answers.

Table 2 Needs analysis results of $3^{\text {rd }}$ year engineering students

\begin{tabular}{|c|c|}
\hline Satisfaction of needs & $\begin{array}{l}\text { - insufficient amount of in-class writing } \\
\text { (lack of practice) } \\
\text { - more focus on vocabulary, grammar and format }\end{array}$ \\
\hline Aim of the writing course & $\begin{array}{l}\text { preparation for departmental studies (writing } \\
\text { reports, assignments, projects, presentations) } \\
\text { preparation for future career (writing CV, } \\
\text { business transactions such as e-mails, petitions, } \\
\text { applications) }\end{array}$ \\
\hline $\begin{array}{l}\text { Current lacks in their writing } \\
\text { skills }\end{array}$ & $\begin{array}{l}\text { - lack of vocabulary } \\
\text { - } \text { grammar } \\
\text { writing formats }\end{array}$ \\
\hline Changes suggested & $\begin{array}{l}\text { - emphasis on in-class writings } \\
\text { - face to face feedback } \\
\text { - increasing the duration of time } \\
\text { - more emphasis on opinion essays } \\
\text { more focus on vocabulary and grammar }\end{array}$ \\
\hline Preferred essay types & $\begin{array}{l}\text { - } \text { advantages and disadvantages } \\
\text { - } \text { cause and effect } \\
\text { opinion }\end{array}$ \\
\hline Approach to be used in the course & $\begin{array}{l}\text { more emphasis on practice along with basic } \\
\text { theoretical knowledge }\end{array}$ \\
\hline Sample writing to be analysed & $\begin{array}{l}\text { - } \text { professional writings } \\
\text { - some pieces of student writings }\end{array}$ \\
\hline Language skills to be improved & $\begin{array}{ll}\text { - } & \text { grammar } \\
\text { - } & \text { vocabulary }\end{array}$ \\
\hline
\end{tabular}

As seen in Table 2, junior engineering students think that a writing course should prepare them both for their departmental studies and future career. Similar to what preparatory school students stated, $3^{\text {rd }}$ year engineering students also stated that they lack vocabulary and grammar knowledge. This is worth emphasizing because although this group of students had taken a course on writing skills, they think it did not improve their vocabulary and grammar knowledge.

Along with the students, the instructors were also asked to share their opinions about the issue. Table 3 demonstrates the ideas put forward by the instructors teaching a writing course in the preparatory school. Teachers who were involved in teaching the current writing courses offered valuable insights for what students need from a writing course. Similar to what the students have stated, the preparatory school instructors also emphasized the importance of using writing topics that are related to the students' field of interests. They also stated the importance of an ESP writing course, rather than a general one they are asked to offer at the current writing course. 
Table 3 Needs analysis results of preparatory school instructors

\begin{tabular}{|l|l|}
\hline Student wants & $\begin{array}{l}\text { - expressing themselves in the best and shortest way } \\
\text { possible }\end{array}$ \\
& $\begin{array}{l}\text { - gaining knowledge of ESP vocabulary } \\
\text { - process writing }\end{array}$ \\
\hline Aim of the writing course & $\begin{array}{l}\text { - } \text { writing that involves ESP vocabulary } \\
\text { - preparing them to write appropriately for } \\
\text { departmental exams }\end{array}$ \\
\hline - contextualizing writing tasks to relate to their future \\
careers
\end{tabular}

Lastly, one assistant professor from the faculty of engineering was also consulted. Table 4 below presents the results. As seen in Table 4, the participant believes that a writing course should aim to enable students to understand the things they read to be able to respond to them in the desired ways. Also, the writing course needs to provide the students with enough practice with special focus on analysing different sentence patterns with sufficient terminology to develop their vocabulary knowledge. Another aspect the participant focuses on related to the course design is that students need face to face collaboration in feedback as part of the assessment process. 
Table 4 Needs analysis results of engineering faculty member

\begin{tabular}{|l|l|}
\hline Student needs & - to overcome the fear of writing in another language \\
\hline Aim of the writing course & $\begin{array}{l}\text { - enabling students to understand what they read and } \\
\text { how they respond to it }\end{array}$ \\
& $\begin{array}{l}\text { - ability to analyse different sentence patterns with } \\
\text { sufficient terminology } \\
\text { - developing vocabulary knowledge } \\
\text { - gaining practical writing skills }\end{array}$ \\
\hline Lacks of the writing course & $\begin{array}{l}\text { - practical writing skills } \\
\text { - the effect of the percentage of actual writing in } \\
\text { grading }\end{array}$ \\
\hline - face to face collaboration \\
\hline Types of writing & $\begin{array}{l}\text { - paragraph writing, to start with } \\
\text { - process writing } \\
\text { - essays (advantages and disadvantages, cause and } \\
\text { effect) }\end{array}$ \\
\hline Topics for writing & $\begin{array}{l}\text { - related to the engineering field, with certain } \\
\text { terminology }\end{array}$ \\
\hline - technical issues \\
- current issues as well
\end{tabular}

\subsection{Principles}

With an attempt to guide the design of the course, enabling researchers to decide on how learning can be encouraged in the best way for the students to benefit from the course, the design of this writing course is based on several principles organized under the categories of content and sequencing, format and presentation, monitoring and assessment, as suggested by the model of language curriculum design by Nation \& Macalister (2010). As Nation \& Macalister (2010) emphasize, teachers today do not tend to follow a particular method or approach directly, since practitioners of a particular method have started to find similarities between methods that were thought to be quite different from each other. Therefore, the design of the course is particularly derived from the needs analysis carried out with in the ESP context.

\subsubsection{Content and sequencing}

The results of the needs analysis show that there is a need for practicing specific types of writing many times so that the students can gain familiarity with the format, vocabulary and grammar. For this reason, students will also be given certain strategies in order to do certain types of writing to use when they are assigned writing tasks out of the class time. This will enable them to be independent and autonomous language learners. Many students state that they cannot make use of the strategies they learn in the writing course in their daily lives and careers. Therefore, this course aims to enable the students to gain this independence. Students 
will also be taught certain grammatical structures and vocabulary that they need to make use of, creative use of the language while doing certain kinds of writing. One of the major problems the students have with practical writing skills is that they are not presented with a progressive approach to writing. In this course, the students will be presented with a progressive approach with sentence writing, paragraph writing and essay writing so that one type of writing will have positive effect on the following one.

It is important the content should help learning in the classroom, suit the proficiency level of the students, reflect what learners want to see in the course as well as be suitable for teachers to comprehend and model, as suggested by Nation and Macalister (2010). Proportionally, $60 \%$ of the course will be based on practicing writing different types of paragraphs and essays as well as other pieces of writings (such as e-mails, letters, etc.), and $40 \%$ will be based on introducing writing types, feedback and discussions. Though practicing different types of writing (such as writing topic sentences, thesis statements, paragraphs and essays) is given priority in the course, the use of appropriate vocabulary in relevant situations while writing, as well as using these in accurate grammatical structures will also be given importance. For these reasons, initial classes aim to revise certain grammatical structures. Another early focus in the course will be given to writing skills such as analysing and outlining to familiarize the students with the structure of writing. Therefore, a bottom-up approach will be used.

Hyland (2003) proposes two approaches to syllabus organization: process-driven and genre-driven, as dominant approaches to second language writing teaching. In designing the course, a genre-driven approach is favoured since the focus is on achievement of purposes in particular contexts for writing through explicit focus on text organization and language choices. The approach includes establishing a context, modelling the genre, noticing, explicit analysis, controlled production, independent writing, and producing the text. Therefore, it is important for the students to read samples first, analyse them to see the organization of such ideas and model them later for their own pieces of written productions. Within the framework of such an approach to the organization of content and due to the nature and components of writing, a linear approach to sequencing is needed since writing a paragraph in a coherent way with appropriate ideas will depend on the ability to form a well thought topic sentence in the

Table 5 Activities and conditions according to four-strand principle

\begin{tabular}{|c|c|c|}
\hline Strand & Conditions & Activities \\
\hline $\begin{array}{l}\text { Language- } \\
\text { focused learning }\end{array}$ & $\begin{array}{l}\text { - The format of the writing } \\
\text { - Unfamiliar grammar structures }\end{array}$ & $\begin{array}{l}\text { - Grammar study } \\
\text { - Explanation made to clarify the } \\
\text { logic behind the different types } \\
\text { of organizations }\end{array}$ \\
\hline $\begin{array}{l}\text { Meaning-focused } \\
\text { input }\end{array}$ & $\begin{array}{l}\text { - The content of the writings } \\
\text { - Certain type of vocabulary }\end{array}$ & $\begin{array}{l}\text { Extensive reading } \\
\text { - Analysing sample writings }\end{array}$ \\
\hline $\begin{array}{l}\text { Meaning-focused } \\
\text { output }\end{array}$ & $\begin{array}{l}\text { - A focus on the content of in- } \\
\text { class writings } \\
\text { - Some unfamiliar language } \\
\text { patterns that students try to use }\end{array}$ & $\begin{array}{l}\text { - In-class writings under the } \\
\text { control of the teacher providing } \\
\text { instant feedback }\end{array}$ \\
\hline $\begin{array}{l}\text { Fluency } \\
\text { development }\end{array}$ & $\begin{array}{l}\text { - Focus on the message } \\
\text { - No unfamiliar language patterns } \\
\text { - Pressure to go faster } \\
\text { - A large quantity of practice }\end{array}$ & $\begin{array}{l}\text { - Individual writing practice } \\
\text { - Writings tasks assigned }\end{array}$ \\
\hline
\end{tabular}


first place; and similarly, writing an essay will depend on combining these paragraphs. In this respect, the syllabus for the course is designed to move from writing a topic sentence to an essay progressively with frequent recycles throughout 14 weeks.

\subsubsection{Monitoring and assessment}

One of the frequently mentioned needs of the students is to have the chance to get feedback by the teacher on a regular basis. Feedback for in-class writings will be provided with face-to-face sessions between the teacher and the students. Similarly, feedback for take-home assignments will be given on the first draft of the student paper. Then, they are expected to write a final draft considering the feedback provided on the first draft so that they will submit the revised version of their first draft. This will increase their awareness on the mistakes and enable them to produce accurate and fluent writing samples. The progress of the students will be constantly monitored by the instructor through in-class writings and face-to-face feedback sessions providing the opportunity for observation of learning. Along with the observation of learning, students are expected to produce different writing tasks individually at home, as part of diagnostic assessment, along with a mid-term and a final exam as part of achievement assessment.

\subsubsection{Goals and objectives}

The specific goals of the EWC for pre-intermediate engineering students are given below. By the end of the course, the students will:

- develop written language skills that will prepare them for exams, presentations, assignments and projects in their major departments

- gain practical writing skills using appropriate vocabulary related to the field of engineering

- gain specific writing skills that will enable them to be independent writers on forms and topic related to their future professional careers

- be able to read, understand and analyse independent, descriptive and narrative paragraphs on a variety of topics related to current issues as well as their field of interest

- be able to read, understand, analyse and produce different essay types, including advantages and disadvantages, cause and effect, argumentative and opinion, on a variety of topics related to their field of study.

\subsubsection{Evaluation}

In Nation and Macalister's (2010) model of language curriculum design, the process of evaluation covers the whole Mercedes symbol, meaning that once a curriculum is designed with all its components and layers, it also needs to be analysed in terms of its efficacy. As Richards (2001) also states, the interlinked system of elements of needs, goals, content, materials and teaching, are the determining factors for a successful design and implementation of a curriculum. However, questions such as "Is the curriculum achieving its goals? Are those affected by the curriculum (e.g., teachers, administrators, students, parents, employers) satisfied with the curriculum?" (p. 286) need to be asked to measure how effective these designing and implementation processes were. 
Brown (1995) defines evaluation as "the systematic collection and analysis of all relevant information necessary to promote the improvement of a curriculum and assess its effectiveness within the context of the particular institutions involved" (p. 218). The emphasis here is on improvement for the better. As Brown (1995) also states, curriculum development never finishes unless a course and/or a program is cancelled totally. Therefore, revisions will always be necessary for future implementations.

There are different types and focuses of evaluating a course/program as proposed by Brown (1995) and Richards (2001). In this project, the course evaluation is based on both process and product-oriented evaluation, with a formative focus. As evaluation is a process within the curriculum design process, not as part of an end assessment, a processoriented approach is necessary with frequent reference to students' and teachers' views on any aspect of the course. Also, a product-oriented approach, we think, is necessary to see how well the students have achieved in the course.

Therefore, the evaluation process of this EWC includes three steps. The first one includes the negotiation of the course content and teachers' way of teaching in general. Upon distributing the syllabus of the course, the students will be asked about their opinions whether the specific tasks and activities in the syllabus represent their needs and wants, as well as addressing their lacks or not. The rationale behind such negotiation is to remove the assumed perspective on the side of the course designers. Even if the syllabus has been written based on principles defined according to the results of the environment and needs analyses, there might still be some inconsistencies between what the students reported and how the designers designed the course.

Additionally, a course evaluation form will be given to the students at the end of the course to evaluate it in terms of: a) course aims and objectives, b) course content and materials, c) activities and methods used in the course, d) assessment, e) teachers' skills and attitudes. The evaluation form is adopted from the Writing Skills 1 Course Evaluation Questionnaire developed by Erozan (2005).

\section{DISCUSSION AND CONCLUSION}

In designing this ESP writing course for pre-intermediate engineering students, the main concern, as well as our starting point were the lacks, needs and wants of the students, which were combined with the experiences and wishes of the instructors both working in the School of Foreign Languages and a lecturer who offers departmental courses to those students who have passed the preparatory school year and started studying at their major departments. The need to design this course derives from the fact that English writing courses offered at Schools of Foreign Languages at Turkish universities aim for a mainstream approach which ignores the specific needs of the students. The fact that there is a diversity in student profile in terms of their university majors requires different approaches to be taken in designing or teaching a particular course, deciding on activities, choosing appropriate forms and functions of vocabulary use, etc. With this in mind, an ESP writing skills course was designed specifically for engineering students, thus trying to eliminate what we call the mainstream effect in such writing courses.

Naturally, this specific course has many strengths and drawbacks. The major strength of the course is that it bases its roots (aims, principles, content and methodology) on the actual needs of the students who will be taking the course along with the experiences of the 
instructors working in the School of Foreign Languages and the wishes of the lecturers offering departmental courses in the Engineering Faculty whose medium of instruction is English. Therefore, upon successful completion of the course, the students are expected to be able to write in ways that will help them both at the departments at the Faculty of Engineering when they finish their preparatory school year and utilize these gains in their professional careers when they graduate from the university. One other strength of the course is that it provides flexibility for the students to have a say on some aspects of the course if they are not satisfied as the course progresses. Though the course takes its roots from their actual prospective benefiters' views, there might still be some things that do not go as planned, both by the curriculum developers and the students. In such circumstances, it is important that the course should provide this flexibility in changing some aspects via negotiation with the course participants. Graves (2000) states that this is a process which might require some changes along the way as "the components are interrelated and each of the processes influences and is influenced by the other in some way" (p. 4).

Along with the advantages, there might be two drawbacks this course might have. Even though there was a detailed needs analysis conducted for the content of this EWC course, there might still be some clashes between personal beliefs/ideologies of the teachers and any part of this course. For instance, some teachers might just not prefer the type of activities integrated by skipping them. Similarly, they might not agree on the assessment procedures which might contradict with their overall teaching philosophies. However, at the end of the term student questionnaires and interviews will be conducted to determine the deficiencies in how the course goes.

Another drawback might stem from the specific focus of this writing course, which might cause a leaving out of some other areas of the writing skill. For instance, due to the lacks and needs of the students, more focus was given on certain types of essays although they are not the only essay types involved in academic writing. While such a focus might not have a problem for the students' academic careers, it could lead to the possibility that the students would eventually pass a writing course but lack some writing skills for their general English proficiency. In order to avoid this, this ESP writing course can be offered as an extension of a writing skills course which covers mainstream writing skills.

\section{Limitations of the study}

Due to time restrictions and impracticality, the researchers could not have connections with the employers of the engineers who would talk about the required qualifications from the engineers for English writing skills. What is more, the researchers could not have the chance to integrate the syllabus with the curriculum.

\section{REFERENCES}

Brown, J. D. (1995). The Elements of Language Curriculum. Boston: Heinle \& Heinle.

Erozan, F. (2005). Evaluating the language improvement courses in the undergraduate ELT curriculum at Eastern Mediterranean University: a case study. Unpublished PhD dissertation. Ankara: Middle East Technical University.

Graves, K. (2000). Designing Language Courses: A Guide for Teachers. Boston, MA: Heinle \& Heinle.

Hyland, K. (2003). Second Language Writing. Cambridge: Cambridge University Press. 
Nation, I. S. P. (2009). Teaching ESL/EFL Reading and Writing. New York: Routledge.

Nation, I. S. P., \& Macalister, J. (2010). Language Curriculum Design. New York and London: Routledge.

Olshtain, E. (2001). Functional task for mastering the mechanics of writing and going just beyond. In M. Celce-Murcia (Ed.), Teaching English as a Second or Foreign Language (pp. 207-217). Boston: Heinle \& Heinle.

Raimes, A. (1983). Techniques in Teaching Writing. Oxford \& New York: Oxford University Press.

Richards, J. C. (2001). Curriculum Development in Language Teaching. Cambridge: Cambridge University Press.

Ur, P. (1996). A Course in Language Teaching. Cambridge: Cambridge University Press.

APPENDIX

PRE-INTERMEDIATE ESP WRITING COURSE SYLLABUS

Course Description

The aim of this course is to introduce students to practical writing skills. As such, the course aims to equip students to understand, analyse and write topics sentences, thesis statements, different paragraph and essay types; to conduct pieces of writings that will help them in their departments while taking exams, make presentations, do projects and assignments; to familiarise them with writing types that they will come across in their professional careers. The emphasis will be on practice including appropriate use of specific field related vocabulary, appropriate use of grammatical structures. The students will be able to write independently at the end of the course. Course Objectives

On successful completion of the course, the students are expected to be able to:

- develop written language skills that will prepare them for exams, presentations, assignments and projects in their major departments

- gain practical writing skills using appropriate vocabulary related to the field of engineering

- gain specific writing skills that will enable them to be independent writers on forms and topic related to their future professional careers

- be able to read, understand and analyse independent, descriptive and narrative paragraphs on a variety of topics related to current issues as well as their field of interest

- be able to read, understand and analyse different essay types, including advantages and disadvantages, cause and effect, argumentative and opinion, on a variety of topics related to their field of study.

Course Conduct

Each session will be based on both theoretical explanations of types of writing as well as practicing these types of writing. In-class writing will be given emphasis.

Course Requirements

A Writing Portfolio: The students will conduct a total of 9 writing tasks that will be given to them as take-home assignments. The students are also expected to conduct pieces of writings in the class time on topics and types discussed for that particular week. These writings will be compiled as a portfolio to be submitted at the end of the course.

Pop Quizzes: There will be 2 pop quizzes that will appear at different times as the course progresses. In these quizzes, the students are required to conduct pieces of writings according to the types and topics discussed in the class.

Midterm and Final Exams 


\begin{tabular}{|c|c|}
\hline \multicolumn{2}{|r|}{ Assessment } \\
\hline \multicolumn{2}{|r|}{ Portfolio: $40 \%$, Pop Quizzes: $10 \%$, Midterm: $20 \%$, Final: $20 \%$, Attendance: $10 \%$. } \\
\hline \multicolumn{2}{|r|}{ Tentative Course Outline } \\
\hline Week 1 & $\begin{array}{l}\text { Introduction of the course content, requirements that students have to follow during the } \\
\text { term and the evaluation criteria. } \\
\text { Meeting the new students and making them express what they expect from the course. } \\
\text { The revision of some grammar topics such as Relative Clauses } \\
\text { Revision of some conjunctions (however, therefore, despite, instead, for instance...) } \\
\text { Revision of some grammatical structures (such as, so that, lest, in case...) }\end{array}$ \\
\hline Week 2 & $\begin{array}{l}\text { Reading independent paragraphs on leisure time activity } \\
\text { Analysing the structure of an independent paragraph on leisure time activities } \\
\text { Topic sentence, supporting sentences, concluding sentence of a paragraph } \\
\text { Analysing the grammatical structures used in the paragraph along with the vocabulary } \\
\text { presented }\end{array}$ \\
\hline Week 3 & $\begin{array}{l}\text { In class independent paragraph writing } \\
\text { Students are to write a paragraph about their leisure time activities } \\
\text { Feedback will be given in the class, face-to-face conversation with the instructor }\end{array}$ \\
\hline Week 4 & $\begin{array}{l}\text { Reading descriptive paragraphs about career opportunities } \\
\text { Students are to write a descriptive paragraph describing their ideal career } \\
\text { Feedback will be given in the class, face-to-face conversation with the instructor will be } \\
\text { provided } \\
\text { Task 1: Students are also assigned to write a paragraph describing their career plans } \\
\text { after graduation as an assignment and they will submit it to the instructor the coming } \\
\text { week }\end{array}$ \\
\hline Week 5 & $\begin{array}{l}\text { Reading descriptive paragraphs about inventions } \\
\text { Students are to write a descriptive paragraph describing dream inventions } \\
\text { Feedback will be given in the class, face-to-face conversation with the instructor will be } \\
\text { provided } \\
\text { Task 2: Students are also assigned to write a paragraph describing their skills, interests } \\
\text { and abilities as an assignment and they will submit it to the instructor next week }\end{array}$ \\
\hline Week 6 & $\begin{array}{l}\text { Reading narrative paragraphs about people's experiences on job applications } \\
\text { Students are to write a CV and statement of purpose explaining their background } \\
\text { Feedback will be given in the class, face-to-face conversation with the instructor will be } \\
\text { provided } \\
\text { Task 3: Students are assigned to write a cover letter for a company they wish to apply } \\
\text { and they will submit to the instructor next week }\end{array}$ \\
\hline Week 7 & $\begin{array}{l}\text { Reading Paragraphs explaining Process (Process Writing) } \\
\text { The topics of the paragraphs read and analysed in the class will be about experimental } \\
\text { studies conducted on engineering } \\
\text { Task 4: Students are to write about an experiment that they are planning to carry out in } \\
\text { the department. They are expected to write the whole process step by step using the } \\
\text { grammatical structures and conjunctions taught to them }\end{array}$ \\
\hline \multicolumn{2}{|r|}{ MID-TERM EXAM } \\
\hline Week 8 & $\begin{array}{l}\text { Reading e-mails, the content of which are the imports and export policies of a company } \\
\text { Students are to write an e-mail to their prospective employer reporting about the details } \\
\text { of a product that their company is planning to export } \\
\text { Feedback will be given in the class, face-to-face conversation with the instructor will be } \\
\text { provided } \\
\text { Task 5: Students are to write an e-mail to their prospective employer reporting about the } \\
\text { details of a product that their company is planning to import }\end{array}$ \\
\hline
\end{tabular}




\begin{tabular}{|c|c|}
\hline Week 9 & $\begin{array}{l}\text { Essay writing } \\
\text { Students will be introduced to the format of an essay and the parts of it: introduction, } \\
\text { body, and conclusion } \\
\text { Students will also be shown how to write a thesis statement, where to put it and how to } \\
\text { write a transition paragraph (if necessary) } \\
\text { Students will be expected to use the knowledge that they have learned until this week. } \\
\text { For example, they will write the body paragraphs in accordance with the format they } \\
\text { have been shown in previous weeks in paragraph writing } \\
\text { An example essay on the benefits of computers will be read and analysed } \\
\text { Task 6: Students are to write the benefits of technology based on the format they have } \\
\text { been shown and they will submit it next week }\end{array}$ \\
\hline Week 10 & $\begin{array}{l}\text { Advantages and disadvantages essay writing } \\
\text { Essays on the advantages and disadvantages of mobile phones, creative inventions and } \\
\text { imported machines will be read and analysed in class } \\
\text { Students are to write an essay on the advantages and disadvantages of the nuclear power } \\
\text { plants } \\
\text { Feedback will be given in the class, face-to-face conversation with the instructor will be } \\
\text { provided } \\
\text { Task 7: Students are to write on advantages and disadvantages of chemical experiments } \\
\text { and they will submit them to the instructor next week }\end{array}$ \\
\hline Week 11 & $\begin{array}{l}\text { Writing an in-class essay on advantages and disadvantages of the internet use. } \\
\text { Feedback will be given in the class, face-to-face conversation with the instructor } \\
\text { Introduction to Cause and Effect Essay Writing } \\
\text { Essays on the causes and effects of global warming, building skyscrapers in the city } \\
\text { centres, dangerous experiments on human life }\end{array}$ \\
\hline Week 12 & $\begin{array}{l}\text { Students are to write an essay on the causes and effects of overuse of computers and } \\
\text { social media } \\
\text { Feedback will be given in the class, face-to-face conversation with the instructor } \\
\text { Task 8: Students are to write an essay on the causes and effects of the new software } \\
\text { programs on the society and people's life and they will submit them to the instructor } \\
\text { next week. }\end{array}$ \\
\hline Week 13 & $\begin{array}{l}\text { Argumentative/opinion essay } \\
\text { Essays on whether there should be nuclear power plants all around the world, the } \\
\text { excessive use of the internet, excessive use of social networking websites by university } \\
\text { students, whether dangerous experiments should be allowed for engineering students, } \\
\text { will be read and analysed in class. } \\
\text { Task 9: Students are to write an argumentative essay on whether engineering candidates } \\
\text { to the prestigious engineering faculties should be selected based on test results. They } \\
\text { will submit them next week to the instructor. }\end{array}$ \\
\hline Week 14 & $\begin{array}{l}\text { Students are to write an argumentative essay on the implementation of English medium } \\
\text { instruction at engineering faculties. } \\
\text { Feedback will be given in the class, face-to-face conversation with the instructor } \\
\text { The evaluation of the whole term and the course with the students } \\
\text { Submission of the Portfolio }\end{array}$ \\
\hline
\end{tabular}

